\title{
13. NANKAI TROUGH AND JAPAN TRENCH LATE CENOZOIC PALEOENVIRONMENTS DEDUCED FROM CLAY MINERALOGIC DATA ${ }^{1}$
}

\author{
Hervé Chamley, Sédimentologie et Géochimie, Université de Lille I \\ and \\ Jean-Paul Cadet and Jacques Charvet, Sciences de la Terre, Université d'Orléans ${ }^{2}$
}

\begin{abstract}
The clay mineralogy and morphology of DSDP Leg 87 sediments, studied from 200 samples and considered together with data from DSDP Legs 57 and 58, are discussed and interpreted in terms of paleoenvironment. Terrigenous influence represents the main factor responsible for clay deposition in the Nankai Trough and Japan Trench, both marked by proximity to Japan, high submarine relief, and high sedimentation rates. The argillaceous diagenesis is of local or minor importance and includes the readjustment of fleecy to lathed smectites. The volcanic influence consists chiefly of a reworking of smectite developed by subaerial alteration of island arc rocks and secondarily of a local alteration of ash beds.

The late Cenozoic clay sedimentation in the Nankai Trough (Sites 582 and 583) underwent a major change during the early Pleistocene. Hemipelagic sediments characterized by a wide range of minerals, derived from various sources characterizing the whole northern Philippine Sea (Leg 58 data), were replaced by turbiditic sediments with clay associations typical of a restricted southern Japanese origin (chiefly illite and chlorite). The mineralogic transition, which roughly parallels the lithologic one, occurs by short successive steps. It appears to express indirectly the tectonic activity of the southern margin of Japan, marked by the subduction of the Shikoku Basin and the formation of the Nankai Trough.

Middle Miocene to Pleistocene sedimentation on the inner part of the Japan Trench (Site 584) corresponds to a regular detrital supply from Japan, with dominant smectite associated with various minerals. Small mineralogic variations occur, determined by the late Cenozoic climatic variations and possibly by the volcanic activity. The Site 584 clay stratigraphy parallels the successions recorded at Sites 438 and 440 (Leg 57), without significant evidence of differential settling. The first deposits recovered at Site 584 correspond to the end of an important geodynamic history, well recorded in the clay stratigraphy of Sites 438 and 439: (1) existence during the Late Cretaceous of a sloped continental landmass, located somewhere east of the drilling area; (2) proximity of the actively eroded "Oyashio landmass" during the late Oligocene; (3) probable initiation of the collapse of this landmass during the latest Oligocene after a strong stage of volcanic activity; and (4) increase of the influence of Japan on sedimentation during the early-middle Miocene.
\end{abstract}

\section{INTRODUCTION}

The Leg 87 drilling program was devoted to the exploration of two Japanese trench complexes (Fig. 1; Leg 87 Scientific Party, 1983; site chapters, Sites 582-584, this volume). The Nankai Trough was drilled at two places, about $8 \mathrm{~km}$ apart. Site $582\left(31^{\circ} 46.5^{\prime} \mathrm{N}, 133^{\circ} 54^{\prime} \mathrm{E}\right.$; three holes; water depth, $4892 \mathrm{~m}$; maximum penetration, $749.4 \mathrm{~m}$ ) is located in the undeformed sediments of the trench floor, about $2 \mathrm{~km}$ south of the deformation front revealed by seismic profiles. About $560 \mathrm{~m}$ of Quaternary trench-fill (turbiditic) sediments overlie lower Quaternary and upper Pliocene hemipelagites of the Shikoku Basin. Site $583\left(31^{\circ} 50^{\prime} \mathrm{N}, 133^{\circ} 51.3^{\prime} \mathrm{E}\right.$; eight holes; water depth, 4663-4673 m; maximum penetration, $450 \mathrm{~m}$ ) is located through the lowest structural terrace of the inner slope of the Nankai Trough: Holes 583B, $583 \mathrm{C}$, and $583 \mathrm{D}$ at the toe of the basal thrust; Holes 583E, 583F, and 583G $500 \mathrm{~m}$ landward; and Hole 583A still $400 \mathrm{~m}$ more landward, crossing the uppermost part

\footnotetext{
${ }^{1}$ Kagami, H., Karig, D. E., Coulbourn, W. T., et al., Init. Repts. DSDP, 87: Washington (U.S. Govt. Printing Office).

2 Addresses: (Chamley) Sédimentologie et Géochimie, ERA 764, Université de Lille I, 59655 Villeneuve d'Ascq. France; (Cadet, Charvet) Sciences de la Terre, ERA 601, Université d'Orléans, 45046 Orléans, France.
}

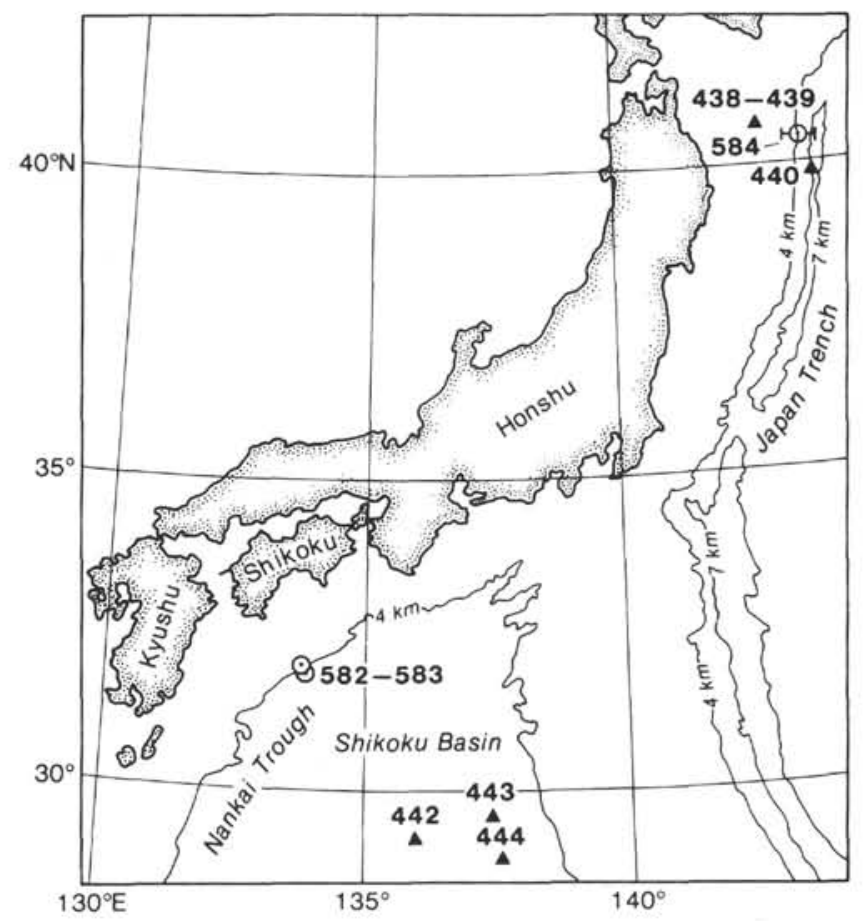

Figure 1. Location of DSDP Sites: Legs 57 (Sites 438 to 440), 58 (Sites 442 to 444 ), and 87 (Sites 582 to 584 ). 
of the section missing in the other holes. Sediments consist of Quaternary dark gray hemipelagic muds with frequently graded sand and silt layers, and with sparse ash and vitric sand. Site $584\left(40^{\circ} 28.0^{\prime} \mathrm{N}, 143^{\circ} 57^{\prime} \mathrm{E}\right.$; three holes; water depth, 4124-4152 m; maximum penetration, $954 \mathrm{~m}$ ) is situated on the deep-sea terrace of the trench slope, approximately $42.5 \mathrm{~km}$ upslope from the Japan Trench axis. Sediments consist of thin Pleistocene and lower Pliocene diatomaceous mud and mudstone (0-231 m); lower Pliocene to upper Miocene diatomaceous mudstone with fine sand and silt beds dipping seaward (231-537 m); and upper to middle Miocene varicolored and bioturbated mudstone with a much reduced diatom content.

\section{METHODS}

The clay mineralogy of 204 samples, regularly located along the Leg 87 cores ( 69 samples from Site 582; 83 from Site 583; 52 from Site 584 ), has been studied by X-ray diffraction on $<2 \mu \mathrm{m}$, oriented pastes. Some selected samples of the different mineralogic units identified have been observed by transmission electron microscopy. Methods have been recorded by Chamley (1980a). The purpose of the study was to participate in reconstructing past environments from clay mineral stratigraphy. Therefore, the results from Leg 87 will be presented first and then discussed together with previous data obtained from Legs 57 (Japan Trench; Chamley and Cadet, 1981) and 58 (Shikoku Basin; Chamley, 1980b; White et al., 1980).
CLAY MINERALOGY OF SITES 582, 583, AND 584

\section{Nankai Trough}

Most of the Pleistocene sediments studied at Sites 582 (Cores 582-1, 582A-1, 582A-2, 582B-2 to 582B-54) and 583 (all cores) contain very similar clay assemblages throughout the stratigraphic column, and the data are easily expressed as average values (Fig. 2; Plate 1, Figs. $1,2)$. Chlorite $(20-35 \%$ of the clay fraction) and illite $(30-50 \%)$ are abundant; smectite is fairly abundant (10$35 \%$ ); irregular mixed-layers (chiefly of illite-smectite and chlorite-smectite types) and kaolinite are minor components $(5-10 \%)$. With regard to associated minerals, quartz and feldspars are common, and amphiboles are rare to fairly common. An example of this homogeneity arises from Holes 583B, 583C, and 583D, drilled one below the other at the same location down to $326.6 \mathrm{~m}$ (Fig. 3). The only significant change recorded concerns Cores 583D-14 to 583D-16, where the smectite abundance reaches $35 \%$ of the clay fraction. Holes $583,583 \mathrm{~A}$, and $583 \mathrm{E}$ to $583 \mathrm{G}$ are marked by assemblages quite similar to these average ones.

The lower Pleistocene and Pliocene sediments of Cores 582B-55 to 582B-73 contain higher amounts of smectite (25-40\% of the clay fraction) than in overlying deposits

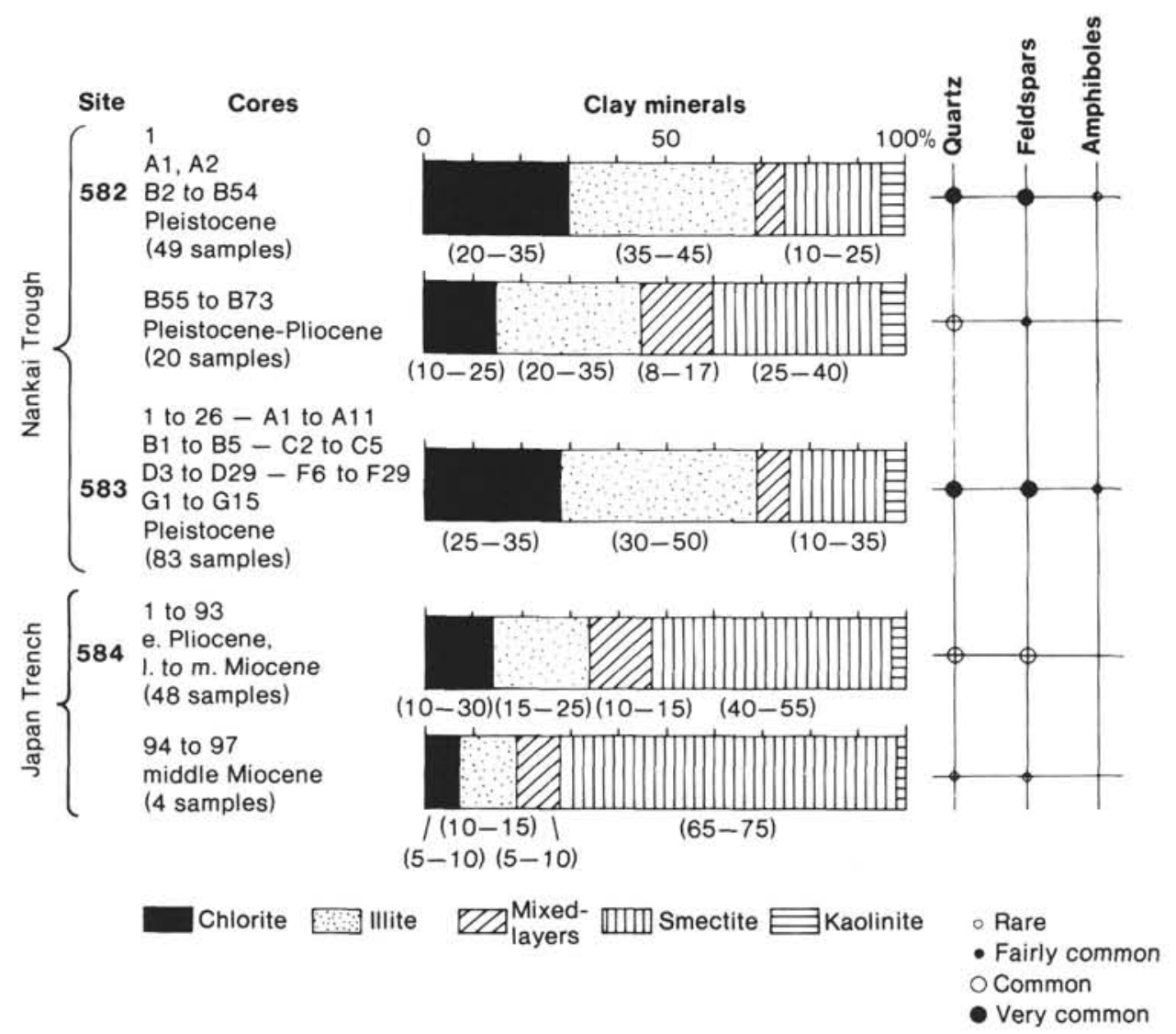

Figure 2. Average clay composition of Leg 87 main mineralogic units. In the Cores column, letters before numbers indicate the hole (e.g., $\mathrm{Al}, \mathrm{A} 2=$ Cores $582 \mathrm{~A}-1$ and $582 \mathrm{~A}-2$ ). If there is no letter, that indicates the first hole of that site (e. g., 1 to 26 = Cores 583-1 to 583-26). Numbers in parentheses in the Clay Mineralogy column show the extreme percentages. 


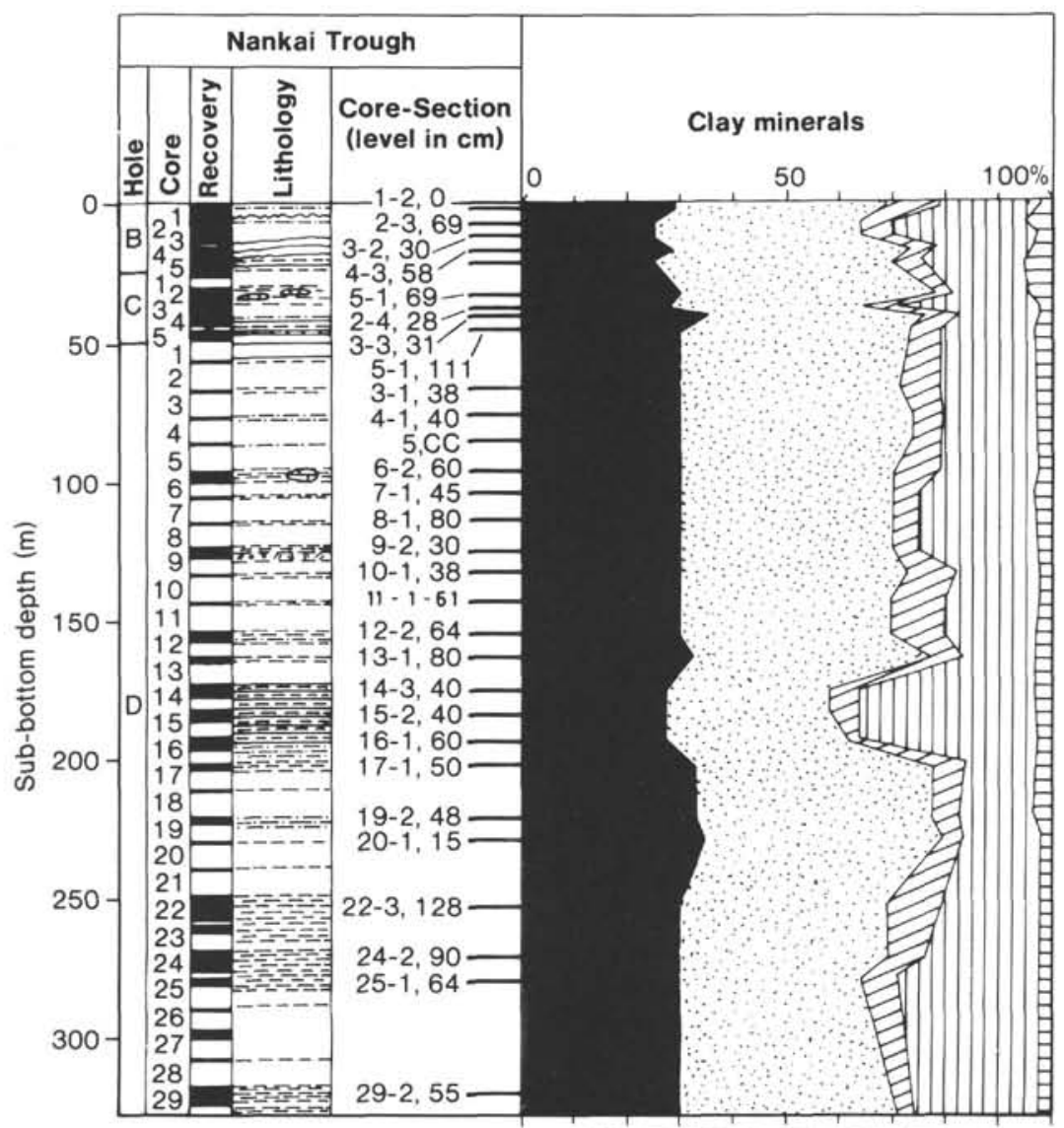

Figure 3. Detailed clay mineralogy of Pleistocene sediments of Holes 583B, 583C, and 583D, Nankai Trough. For key, see Figure 2. For lithologic symbols, see Explanatory Notes chapter (this volume).

(Figs. 2 and 4). The expandable mineral typically consists of fleecy or lathed particles (Plate 1, Figs. 3, 4) and corresponds to a decrease of quartz and feldspar abundance and to the absence of amphiboles. Irregular mixed-layers are fairly abundant $(8-17 \%)$ and diversified (including vermiculitic and smectitic types), whereas the abundances of chlorite (10-25\%) and illite (20$35 \%)$ are lower than in more recent Pleistocene deposits.

\section{Japan Trench}

The lower Pliocene to upper middle Miocene sediments of Site 584 (Cores 584-1 to 584-93) contain homogeneous assemblages, characterized by abundant fairly well crystallized smectite (40-55\% of the clay fraction), associated with fairly abundant chlorite $(10-30 \%)$ and illite (15-25\%), some mixed-layers (10-15\%, mostly smectitic types), and kaolinite (traces to 5\%). Associated minerals include common quartz and feldspars, and common to abundant opal, essentially of biogenic origin (Figs. 2 and 5; Plate 1, Fig. 5).

In the lowermost part of Hole 584 (middle Miocene, Cores 584-94 to 584-97), smectite abundance increases markedly (65-75\% of the clay fraction), and other minerals are present in small amounts (especially kaolinite, quartz, and feldspars). Smectite particles present both fleecy and lathed structures. Biogenic silica, frequently as abundant as in the overlying units (Plate 1, Fig. 6), is probably responsible for the poor crystallinity of the minerals observed by X-ray diffraction on oriented pastes.

\section{ORIGIN OF CLAY MINERALS IN NANKAI TROUGH PLEISTOCENE SEDIMENTS}

The illite-rich and chlorite-rich assemblages, which characterize most of Pleistocene sediments at Sites 582 and 583 (Figs. 2 and 3), typically proceed from the erosion of igneous, metamorphic, and pre-Cenozoic sedimentary rocks, widely outcropping on the southern Japanese islands and responsible for a large part of the sedimentation in peri-Japanese seas (Aoki and Oinuma, 1974; Aoki et al., 1974; Huang and Chen, 1975; Murdmaa et al., 1977; Kolla et al., 1980; Chamley, 1980b). The remarkable abundance in Nankai Trough of illite and chlorite, associated with noticeable amounts of irregular mixed-layers, quartz, feldspars, and amphiboles, points to the large influence of southern Japan, where these minerals are abundantly present in rocks and superficial soil formations (Sudo and Shimoda, 1978). Such a strong correspondence between the petrography of the subaerial rocks and the clay mineralogy of the adjacent marine sediments is in agreement with the lithologic and geomorphologic data, showing that the Quaternary sediments at Sites 582 and 583 are chiefly turbidites, essentially fed axially from a source near the Japanese Izu pe- 


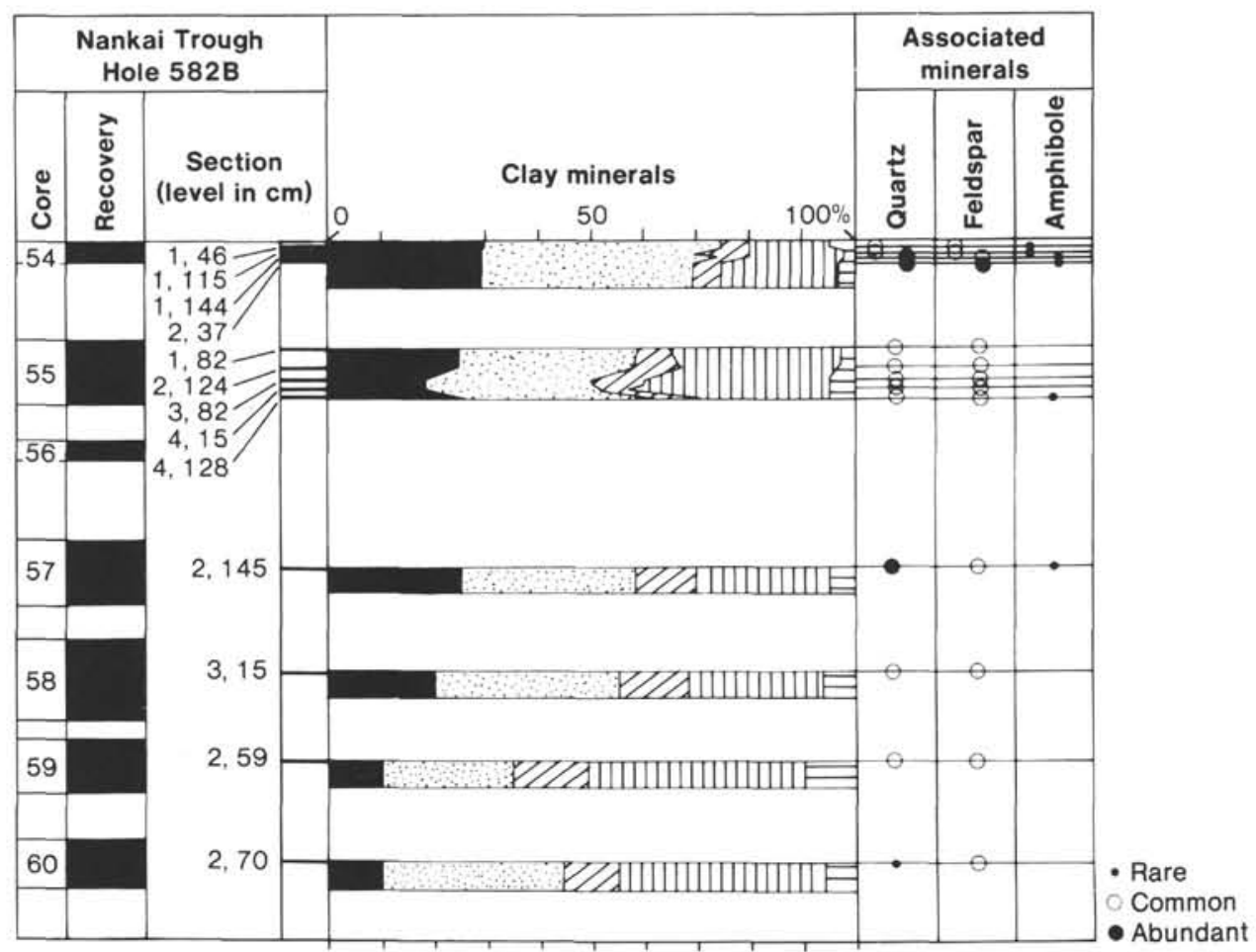

Figure 4. Clay mineralogy at the hemipelagite-turbidite boundary of Hole 582B lower Pleistocene sediments. For key, see Figure 2.

ninsula, about $400 \mathrm{~km}$ northeast of the drilling area (Leg 87 Scientific Party, 1983). The smectite and kaolinite associated with the illite and chlorite group are also chiefly supplied by turbiditic currents from Japan, where they do exist in various rocks and soils (Kobayashi et al., 1964; Aoki and Oinuma, 1974; Aoki et al., 1974; Sudo and Shimoda, 1978). The minor changes observed in the mineral percentages along the stratigraphic column probably result from variations in the turbiditic regime and from the Quaternary alternations of climate determining the continental pedogenic alterations (Chamley, 1980b; 1981).

\section{INFLUENCE OF SEDIMENTARY REGIME, DIA- GENESIS, VOLCANISM, AND TECTONICS ON LATE CENOZOIC CLAY SEDIMENTATION IN THE NANKAI TROUGH}

The lower Pleistocene to Pliocene sediments at the base of Site 582 (Cores 582-55 to 582-73) contain more diversified clay assemblages than the overlying Pleistocene deposits (Figs. 2 and 4). The oldest clay associations at Site 582 strongly resemble those of late Cenozoic sediments at Sites 442,443 , and 444 , located south of the Nankai Trough in the Shikoku Basin (Chamley, $1980 \mathrm{~b})$. The common characteristic of these sediments is their hemipelagic depositional regime, corresponding to the supply in the northern Philippine Sea of minerals from different major sources (Fig. 6): illite and chlorite from Japan and eastern Asia; smectite from volcanic arcs; irregular mixed-layers from various weathered soil profiles; kaolinite from Southeast Asia and also Japan; and vermiculite and sometimes palygorskite (attapulgite) from Asia. As a consequence, the region of Nankai
Trough appears to have been dependent, until the early Quaternary, on the general sedimentary regime prevailing in the northern Philippine Sea, a regime marked by open circulation of water masses leading to the mixing of fine detrital minerals from various sources. The major change to a turbiditic sedimentary regime, occurring at about $0.65 \mathrm{Ma}$ (Leg 87 Scientific Party, 1983), is clearly expressed by the clay mineral assemblage and corresponds to a strong geographic restriction of the detrital input, the Japanese islands remaining nearly the only source of clay minerals. Clay associations appear to represent useful markers of the major modifications occurring in the terrigenous sources, responsible for a large part of the late Cenozoic marine sedimentation in the Nankai Trough area.

The major change in the early Pleistocene sedimentation, that is, a shift from a hemipelagic to a turbiditic regime, probably resulted from tectonic activity in the northern Philippine Sea. In particular, this activity was marked by northward subduction, thrusting, and the formation of the Nankai Trough. Sedimentation expresses this tectonic activity in different ways: unhealed fractures dipping near $40^{\circ}$, dip-slip grooves and striae, dewatering veinlets (Karig et al., 1983; Leg 87 Scientific Party, 1983; site chapters, Sites 582 and 583, this volume). As far as the clay sedimentation is concerned, the only obvious expression of this tectonic activity appears to be the change from various terrigenous sources to a single source, occurring during the early Pleistocene (Site 582, close to $560 \mathrm{~m}$ ) and corresponding to the modification in the depositional regime and probably to the deepening of the Nankai Trough. Note that this change was not instantaneous, but marked by several 


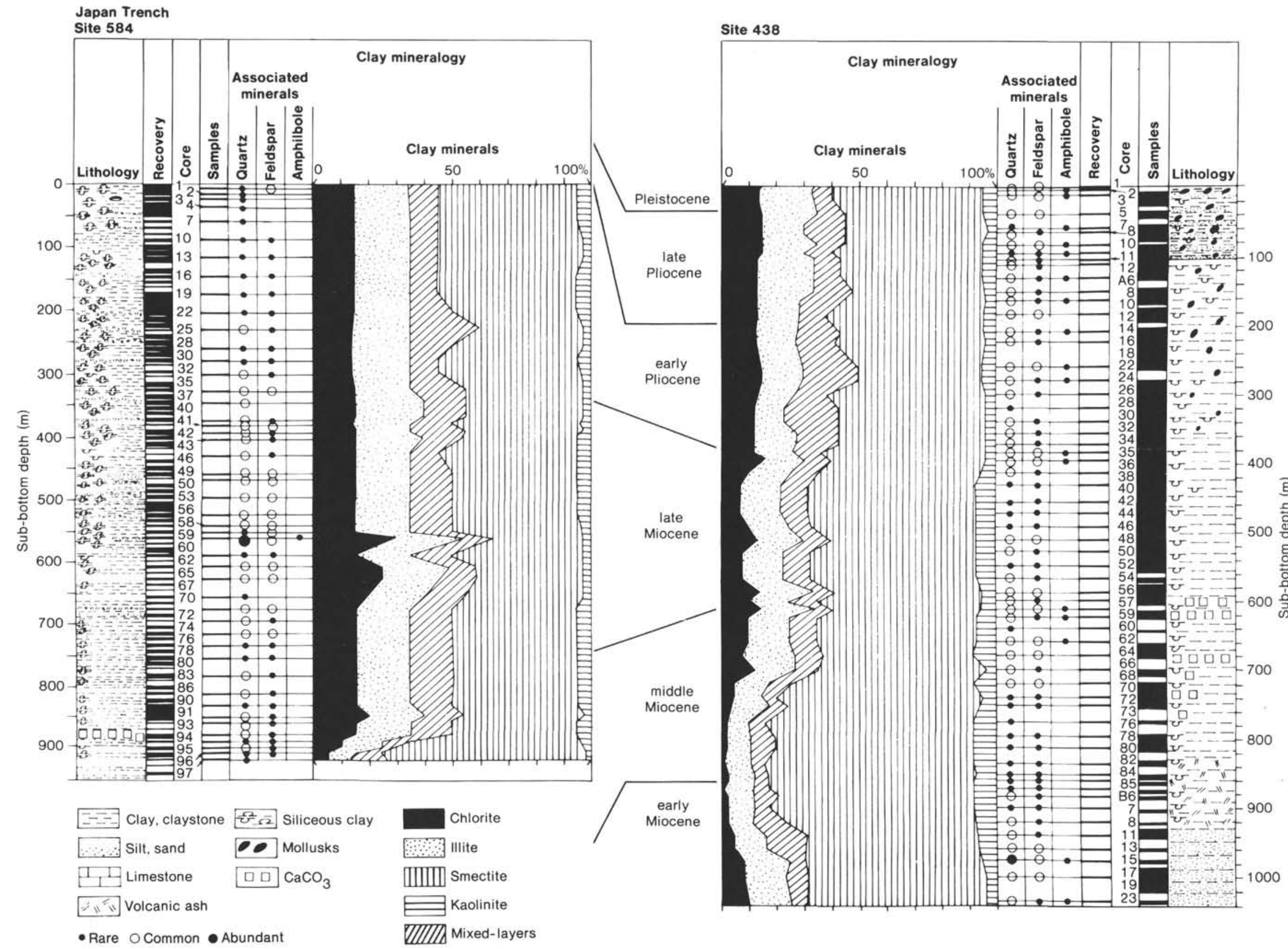




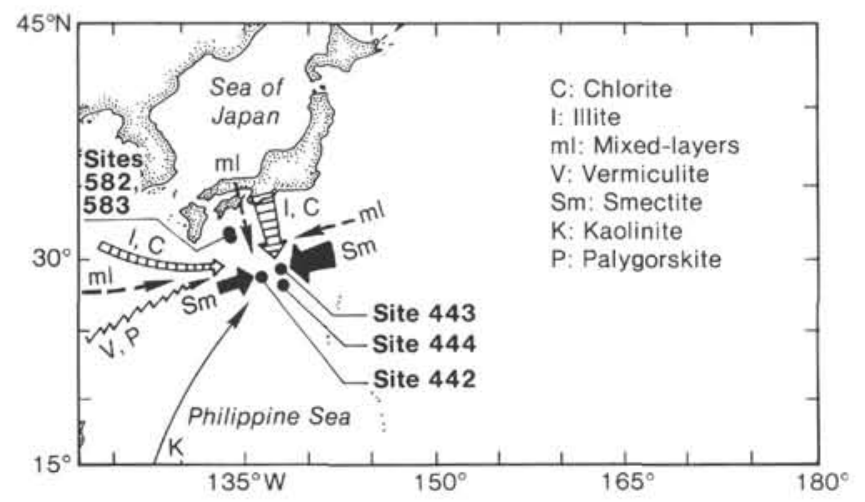

Figure 6. Main sources of clay minerals in the Shikoku Basin (from Chamley, 1980b).

steps, with the smectite amount decreasing and the illite group increasing irregularly upwards from Core 582-59 to Core 582-54 (Fig. 4).

A general lack of other evidence of tectonic activity revealed in the clay sedimentation is in agreement with the low subduction rate and the subtle and limited smallscale structures in the sedimentary column itself (Karig et al., 1983). The thrust surface crossing Hole 583D near $160 \mathrm{~m}$, and deduced from the seismic reflection profile (Leg 87 Scientific Party, 1983), could correspond to the only significant mineralogic change in the sedimentary successions in Holes 583B, 583C, and 583D: Cores 14, 15 , and 16 of Hole 583D show a moderate increase of smectite abundance, between about 170 and $200 \mathrm{~m}$ below mudline (Fig. 3). This temporary variation could result from an increase of the volcanic activity or a lesser dependence on supply from Japanese sources and could also be contemporary to an epeirogenic destabilization. The existence of a hanging-wall splay intersecting Hole 583D near $60 \mathrm{~m}$ sub-bottom and of a structural terrace at Hole 583A only (also deduced from the reference seismic profile) is not corroborated by any peculiarity of the clay sedimentation.

The relatively high amount of smectite in the Pliocene to lower Pleistocene sediments of Site 582 probably depends on the active volcanism characterizing the island arcs surrounding the Shikoku Basin during the late Cenozoic (Huang and Chen, 1975; Murdmaa et al., 1977; Kolla et al., 1980; Chamley, 1980a, 1980b). Lithologic, mineralogic, micromorphologic, and geochemical observations suggest that northern Philippine Sea smectites chiefly derive from the subaerial erosion and transport of volcanic material. The submarine influence of volcanism on the clay formation is obvious only within the basalts themselves, at the precise contact between the basalts and the sediments (Chamley and Bonnot-Courtois, 1981), or in local ash layers marked by a larger exchange activity (Chamley, 1980a). Other diagenetic processes may affect the smectites, especially the growth of lathed structures at the periphery of fleecy particles (Plate 1). But these modifications are not necessarily related to a volcanic influence and can develop without significant modifications of the clay mineral composition (Holtzapffel and Chamley, 1983).

\section{NATURE OF LATE CENOZOIC MINERAL SEDIMENTATION IN THE JAPAN TRENCH}

Diversity of clay minerals, but homogeneity of the sedimentary column (Figs. 2 and 5), characterize the middle Miocene to Pleistocene sedimentation at Site 584, off the Kitakami massif of northern Honshu Island, on the inner part of the Japan Trench. These attributes are similar to those encountered for the same periods at Sites 438 and 440 of Leg 57 (Fig. 5).

The clay mineral assemblages, marked by abundant smectite, fairly abundant illite, chlorite and irregular mixed-layers, and little kaolinite, are typical of the diversified detrital contribution issued from and deposited around the Japanese islands (Sudo and Shimoda, 1978; Kobayashi et al., 1964; Aoki and Oinuma, 1974; 1980; Chamley, 1980b; Kolla et al., 1980). The absence of significant change in the average clay composition from Site 438 to Sites 584 and 540 is due to similar distances of the three sites from the Japanese coast (Fig. 1), precluding differential settling processes. The terrigenous supply arrives at these sites primarily by marine transport, as suggested by the topography of the submarine Japanese margin, by the high sedimentation rates (20 to $200 \mathrm{~m} / \mathrm{Ma}$; Leg 87 Scientific Party, 1983), and by the presence of water-transported quartz (Le Mut, 1980). Eolian transport probably also occurs, as indicated by the presence of common silt and clay-sized quartz (Fig. 5). But this component is much less important volumetrically, than in eastern and northern parts of the northwest Pacific where wind-blown sediments are widely dispersed and easily recognizable in bottom samples (Leinen and Heath, 1981; Rea and Janecek, 1982; Lenôtre et al., in press).

The minor variations recorded in the clay mineralogic composition since the late middle Miocene are chiefly due to the effect of climatic change on the weathering of land masses and to fluctuations in the position of the main water masses carrying the suspended matter (Mann and Müller, 1980). Parallel augmentations of illite and chlorite, often associated with mixed layers and quartz, probably correspond to cooler stages on land, whereas increases of the smectite and kaolinite abundance indicate warmer stages. To deduce detailed climatic scale from clay mineralogic stratigraphy would require denser samples. This lack of a sedimentologic data base thus prevents a clay mineral stratigraphy of Sites 584 and 438, a stratigraphy that at present, mostly relies on diatom assemblages (Fig. 5). The influence of volcanism on clay mineralogy appears to be restricted to the ash layers (Cadet and Fujioka, 1980) and to not affect significantly the common muds and mudstones actively deposited since the middle Miocene.

\section{CENOZOIC HISTORY OF THE NORTH JAPAN MARGIN FROM CLAY STRATIGRAPHY}

The clay assemblages off northern Japan change in the middle Miocene. Smectite contents are higher in Cores 584-94 to 584-97 (Fig. 5), but the main changes occurred before the middle Miocene and were also recorded at Site 439 of Leg 57 (Scientific Party, 1980). We 
refer below to the clay stratigraphy established at Sites 438 and 439 (Chamley and Cadet, 1981) and consider the evolution of the paleoenvironment in chronological order (Figs. 7 and 8).

The Upper Cretaceous silicified and folded claystones and siltstones occurring at the bottom of Site 439 contain abundant chlorite and illite (each mineral forming $40-50 \%$ of the clay fraction), with few mixed-layers (illite-smectite and illite-vermiculite), and common quartz, feldspars, and amphiboles. Such a fairly simple assemblage does not correspond to the petrographic diversity found on the Japanese islands and indicates the active erosion of strongly sloped crystalline or metamorphic rocks. The fine-grained rocks could have derived from a continental landmass located east of Japan, at a fairly long distance from the drilling area as indicated by the fine grain-size of the sediments. This landmass could have been a precursor of the Cenozoic "Oyashio landmass" (Scientific Party, 1980).

After a long hiatus during the major part of the Paleogene, the upper Oligocene deposits at Leg 57 sites show three short mineralogic stages, marked by important variations (Fig. 7).

First, the lowermost clays and siltstones ( $1.5 \mathrm{~m}$ thick) include the same upper Cretaceous minerals and also noticeable amounts of well-crystallized kaolinite $(20 \%$ of the clay fraction) and abundant quartz. This compo- sition indicates the existence of a strongly eroded landmass different from Japan and contributing materials that issued from both continental rocks and evolved soil profiles. The landmass was probably the "Oyashio landmass" (Scientific Party, 1980; Von Huene et al., 1982), located close enough to the drilling area to allow its identification from exoscopic and endoscopic studies of siltysandy quartz (Le Mut, 1980).

Second, the matrix of intermediate dacitic conglomerates (about $40 \mathrm{~m}$ thick) consists of highly crystallized smectite ( $100 \%$ of the clay fraction) and abundant feldspars. The clay mineralogy indicates the rapid alteration of volcanic materials, produced at about $23 \mathrm{Ma}$ (Scientific Party, 1980). The large size of volcanogenic pebbles, together with the mineralogic pureness of their alteration products, point to the proximity of the effusive activity, which was perhaps contemporaneous with the subsidence of the Oyashio landmass.

Third, the uppermost Oligocene sediments consist of fossiliferous sandstones and siltstones (about $100 \mathrm{~m}$ thick). The clay mineralogy suddenly presents a diversified assemblage, including dominant smectite $(40-80 \%$ of the clay fraction), fairly abundant illite (10-30\%) and chlorite (5-25\%), some irregular mixed-layers (traces up to $5 \%$ ) and kaolinite (traces up to $5 \%$ ), abundant quartz, common feldspars, and rare amphiboles. This assemblage resembles the clay suite derived from Japan dur-

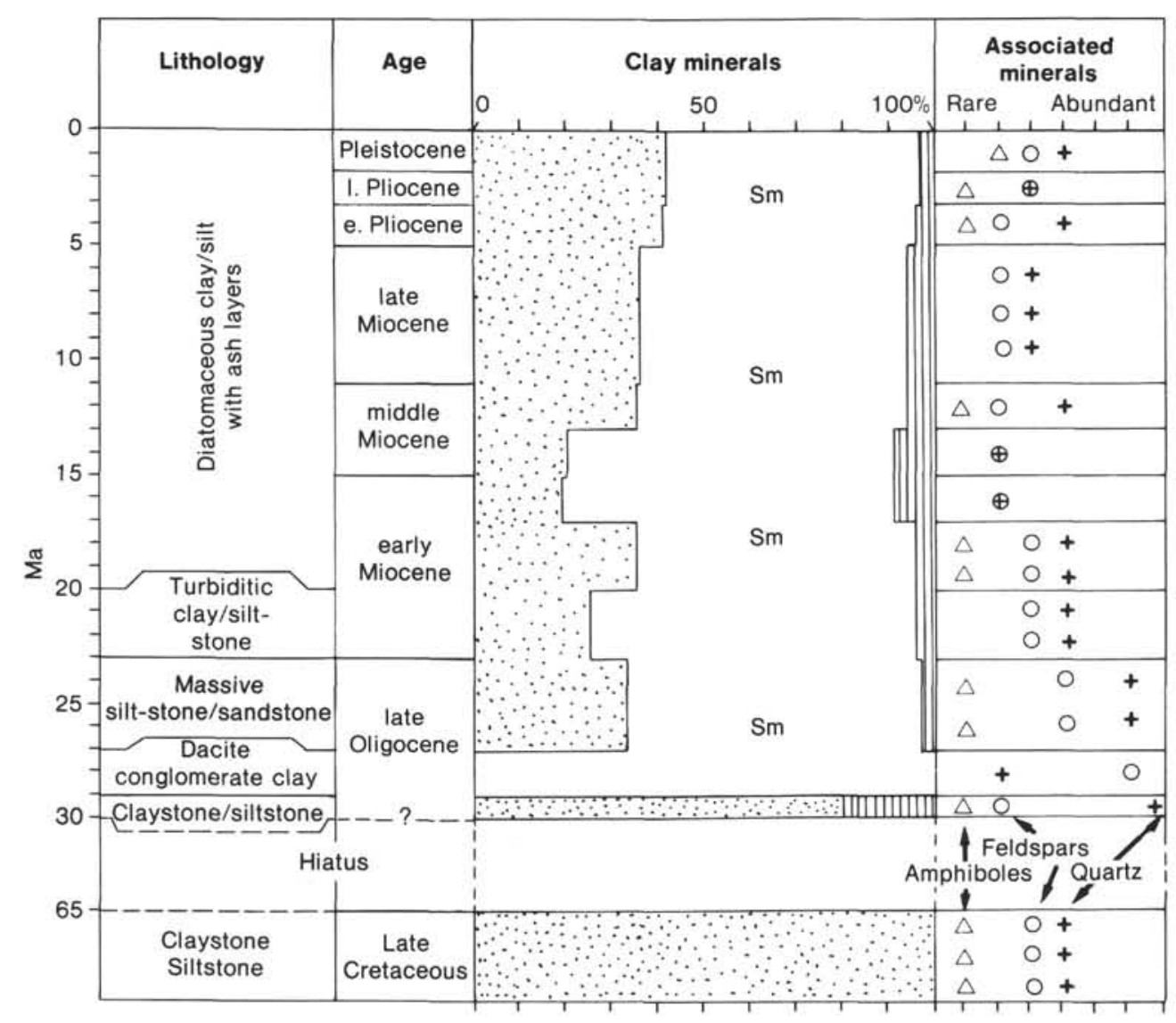

Figure 7. Major Cenozoic mineralogic assemblages of the Japan Trench inner slope (from Chamley and Cadet, 1981). For key, see Figure 2. Sm = smectite. 

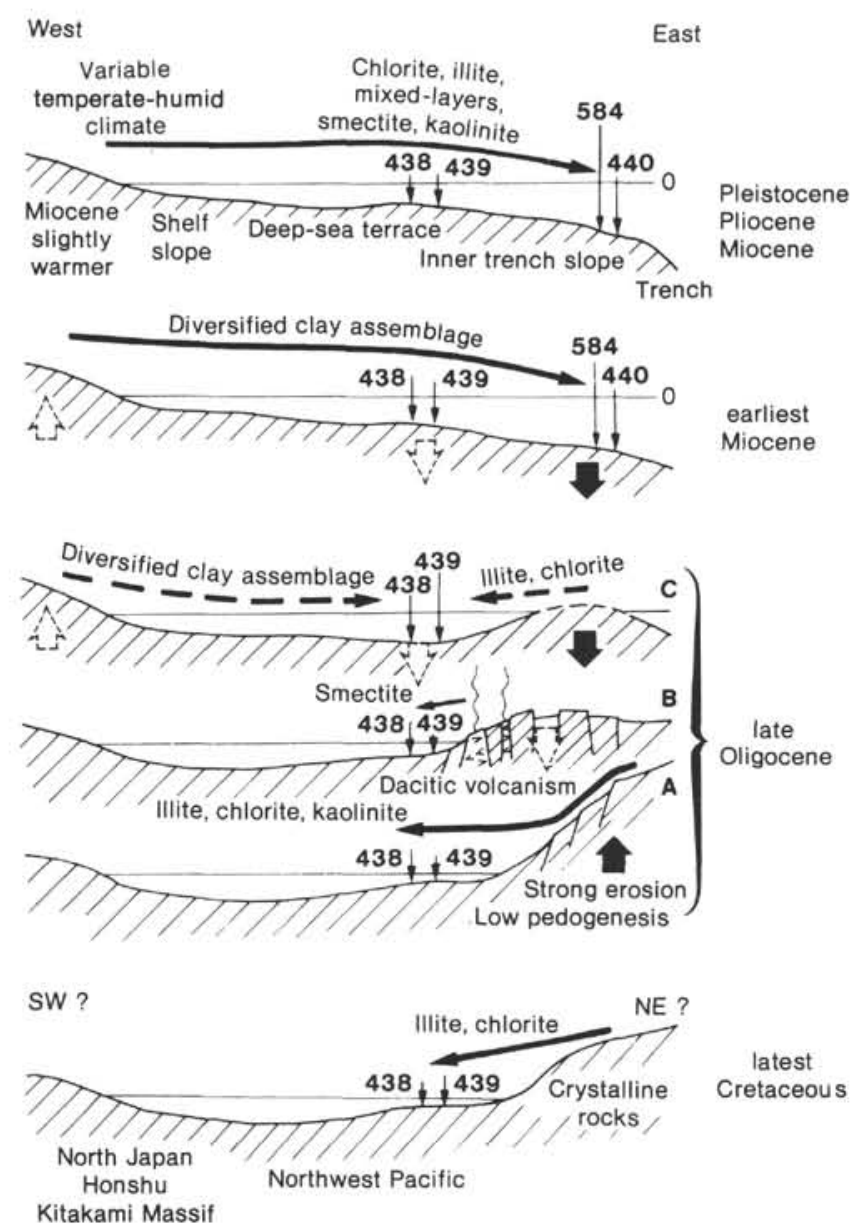

Figure 8. Paleoenvironmental interpretation of Cenozoic clay stratigraphy off northern Japan (after Chamley and Cadet, 1981).

ing the late Cenozoic, but probably with a higher contribution of smectite altered from volcanic rocks or from soils developed under a hot climate having strong seasonal contrasts in humidity (Chamley, 1980a; 1980b). This mineralogic stage suggests that the first periods of collapse and subsidence of the Oyashio landmass took place as early as during the latest Oligocene and led to a submarine morphology not very different from the Neogene, allowing the transport of Japan-derived minerals to the drilling area of Legs 57 and 87B.

The lower to middle Miocene alternating clays, silts, and sandy turbidites (about $200 \mathrm{~m}$ thick) do not show clay mineralogic changes to be as important as the $\mathrm{Pa}$ leogene deposits and primarily reflect the detrital supply issued from Japan. Smectite abundance moderately increases at the transition from middle to upper Miocene (Cores 438B-9 to 438B-6 and Cores 438A-85 to 438A-72), possibly because of climatic changes (more arid, hot climate?). This period corresponds to the definite subsidence of the Oyashio landmass, according to geophysical, micropaleontologic and exoscopic evidence (Scientific Party, 1980; Le Mut, 1980). On the basis of clay mineralogic data, this period must correspond to the end of this major geodynamic event (Fig. 8).
Drilling at Site 584 ended in upper middle Miocene diatomaceous mudstones, deposited after the major physiographic and paleoenvironmental modifications of the eastern Japan margin. These sediments chiefly express the water masses and climate changes, as do the sediments continuously and rapidly deposited above them during the entire late Cenozoic. Clay diagenesis, locally marked by lathed facies at the periphery of smectite sheets (Pl. 1, Fig. 6), remains of moderate importance, as it is in all Cenozoic sediments rapidly deposited on the northwestern Pacific margins.

\section{ACKNOWLEDGMENTS}

We are grateful to the Leg 87 shipboard party for fruitful sampling and stimulating discussions, to M. Bocquet, J. Carpentier, F. Dujardin, and P. Recourt for efficient technical assistance, and to W. Coulbourn and E. Whalen for very useful manuscript corrections. Financial support for the study was provided by Action Thematique Programmée Géologie et Géophysique des Océans 1983 of the Centre National de la Recherche Scientifique, France.

\section{REFERENCES}

Aoki, S., and Oinuma, K., 1974. Clay mineral compositions in recent marine sediments around Nansei-Kyoto islands, south of Kyushu, Japan. J. Geol. Soc. Jpn., 80:57-63.

1980. The distribution of clay minerals in bottom sediments in the Okhotsk Sea to the South China Sea, along the Asiatic continent. Proc. 26th Internat. Geol. Congr., Paris, 2:425. (Abstract)

Aoki, S., Oinuma, K., and Sudo, T., 1974. The distribution of clay minerals in the recent sediments of the Japan sea. Deep-Sea Res., 21:299-310.

Cadet, J.-P., and Fujioka, K., 1980. Neogene volcanic ashes and explosive volcanism: Japan Trench transect, Leg 57, Deep Sea Drilling Project. In Scientific Party, Init. Repts. DSDP, 56, 57, Pt. 2: Washington (U.S. Govt. Printing Office), 1027-1041.

Chamley, H., 1980a. Clay sedimentation and paleoenvironment in the area of Daito Ridge (northwest Philippine Sea) since the early Eocene. In Klein, G. de V., Kobayashi, K., et al., Init. Repts. DSDP, 58: Washington (U.S. Govt. Printing Office), 683-693.

,1980b. Clay sedimentation and paleoenvironment in the Shikoku Basin since the middle Miocene (Deep Sea Drilling Project Leg 58, north Philippine Sea). In Klein, G. de V., Kobayashi, K., et al., Init. Repts. DSDP, 58: Washington (U.S. Govt. Printing Office), 669-681.

1981. Long-term trends in clay deposition in the ocean. Oceanol. Acta, Spec. Issue, pp. 105-110.

Chamley, H., and Bonnot-Courtois, C., 1981. Argiles authigènes et terrigènes de l'Atlanique et du Pacifique NW (Legs 11 et 58 DSDP): apports des terres rares. Oceanol. Acta, 4:229-238.

Chamley, H., and Cadet, J.-P., 1981. Tectonique, volcanisme, morphologies et climats cénozoïques au large du Japon, d'après la sédimentation argileuse marine. C. $R$. Seances Acad. Sci., Ser. D, 292:219-224.

Holtzapffel, T., and Chamley, H., 1983. Morphologie et genèse de smectites albo-aptiennes et paléogènes de l'Atlantique Nord: héritage et recristallisation. C. R. Seances Acad. Sci., Ser. 2, 296: 1599-1602.

Huang, T.-W., and Chen, P.-Y., 1975. The abyssal clay minerals in the West Philippine Sea. Acta Oceanogr. Taiwani., 5:37-63.

Karig, D. E., Kagami, H., and DSDP Leg 87 Scientific Party, 1983. Varied responses to subduction in Nankai Trough and Japan Trench fore arcs. Nature, 304 (5922):148-151.

Kobayashi, K., Oinuma, K., and Sudo, T., 1964. Clay mineralogy of recent marine sediments and sedimentary rocks from Japan. Sedimentology, 3:233-239.

Kolla, V., Nadler, L., and Bonatti, E., 1980. Clay mineral distributions in surface sediments of the Philippine Sea. Oceanol. Acta, 3: 245-250.

Leg 87 Scientific Party, 1983. Leg 87 drills off Honshu and SW Japan. Geotimes, 28 (1):15-18. 
Leinen, M., and Heath, G. R., 1981. Sedimentary indicators of atmospheric activity in the Northern Hemisphere during the Cenozoic. Palaeogeogr., Palaeoclimatol., Palaeoecol., 36:1-21.

Le Mut, C., 1980. Application de l'exoscopie et de l'endoscopie des quartz à l'étude du paléoenvironnement marin. Exemple de la marge active du Japon. C. R. Seances Acad. Sci., Ser. D, 290:1193-1196.

Lenôtre, N., Chamley, H., and Hoffert, M., in press. Nature and significance of Sites 576 and 578 clay stratigraphy (Leg 86 DSDP, northwestern Pacific). In Heath, G. R., Burckle, L. J., et al., Init. Repts. DSDP, 86: Washington (U.S. Govt. Printing Office).

Mann, U., and Müller, G., 1980. Composition of sediments of the Japan Trench transect, Legs 56 and 57, Deep Sea Drilling Project. In Scientific Party, Init. Repts. DSDP, 56, 57, Pt. 2: Washington (U.S. Govt. Printing Office), 939-977.

Murdmaa, J. O., Demidenko, Y. L., Jurnosov, V. B., and Faustov, S. S., 1977. Composition and rates of accumulation of clayey sediments in the Philippine Sea. Oceanology, 17:318-321.

Rea, D. K., and Janecek, T. R., 1982. Late Cenozoic changes in atmospheric circulation deduced from North Pacific eolian sediments. Mar. Geol., 49:149-167.
Scientific Party, 1980. Init. Repts. DSDP, 56, 57: Washington (U.S. Govt. Printing Office).

Sudo, T., and Shimoda, S. (Eds.), 1978. Developments in Sedimentology, Vol. 26: Clays and Clay Minerals of Japan: Amsterdam (Elsevier Scientific Publishing Company).

von Huene, R., Langseth, M., Nasu, N., and Okada, H., 1982. A summary of Cenozoic tectonic history along the IPOD Japan Trench transect. Geol. Soc. Am. Bull., 93:829-846.

White, S. M., Chamley, H., Curtis, D., Klein, G. de V., and Mizuno, A., 1980. Sediment synthesis: Deep Sea Drilling Project Leg 58, Philippine Sea. In Klein, G. de V., Kobayashi, K., et al., Init. Repts. DSDP, 58: Washington (U.S. Govt. Printing Office), 963-1013.

Date of Initial Receipt: 18 January 1984

Date of Acceptance: 14 June 1984 

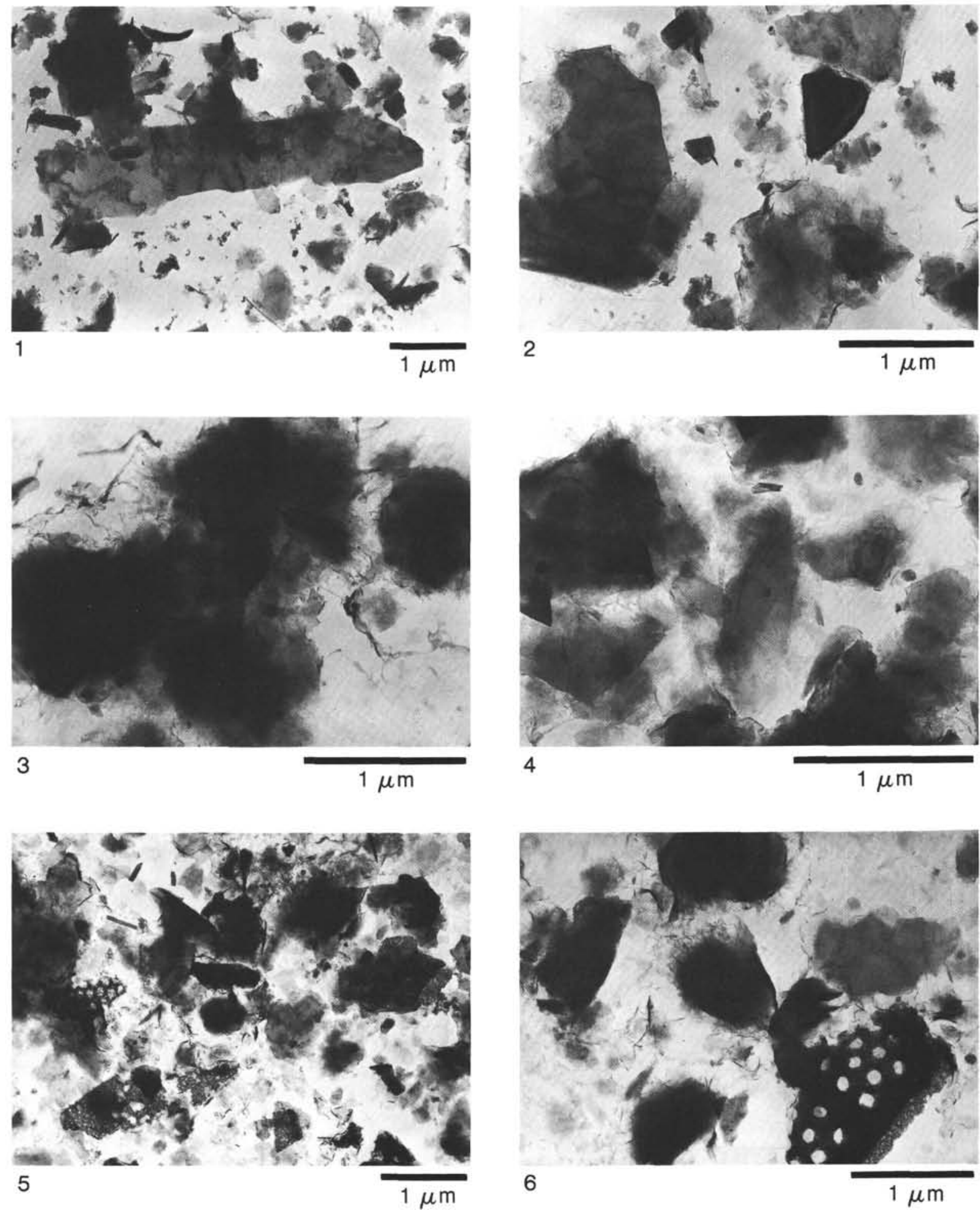

Plate 1. 1, 2. Nankai Trough; 582B-52-1, $53 \mathrm{~cm}$; lower Pleistocene illite-rich and chlorite-rich assemblage; mostly well-shaped particles. 3, 4. Nankai Trough; 582B-60-2, $70 \mathrm{~cm}$; lower Pleistocene smectite-rich assemblage; mainly fleecy and lathed facies. 5. Japan Trench; 584-60-2, $18 \mathrm{~cm}$; upper Miocene; illite, chlorite, and smectite in similar amounts; few kaolinite hexagons, debris of partly dissolved biogenic silica. 6. Japan Trench; 584-96-2, $143 \mathrm{~cm}$; middle Miocene; dominance of fleecy and lathed smectites, siliceous biogenic debris. 